\title{
三宅島における火山ガス放出下の 災害復旧対策の展開過程
}

\author{
石原肇* \\ Development Process of Countermeasures for Disaster Restoration \\ in an Environment Where Volcanic Gases Were Discharged \\ on Miyake Island, Central Japan
}

Hajime ISHIHARA*

\begin{abstract}
The purpose of this research is to investigate how the Anti-disaster Headquarters of Tokyo Metropolitan Government has executed restoration measures for mudflow damage caused by volcanic activity on Miyake Island since June 2000. Most of the restoration of the major ring road along the coast was conducted during the first period from April 2001 to March 2002, aiming at securing the fundamental transportation system for living and reconstruction activities, water and energy supply, communication, and others. The second period from April 2002 to March 2004 was directed for the restoration of other roads including paths that access inland woodlands, and the construction and maintenance of a large number of erosion-control facilities in gullies dissected by volcanic activity. Similar restoration measures were continued and extended to parts of the interior and upstream zones, where watershed management works were also started during the third period from April 2004 to March 2006. In sum, the countermeasures policy for disaster restoration first gave priority to the restoration of roads, particularly those along the coast at first, then shifted attention to the construction and maintenance of erosion-control facilities in and along inland gullies, followed by watershed management works in upstream zones. The sequential and areal shifts of targets of countermeasures for disaster restoration have been made with a perception change among administrative bodies that recognized the effects of volcanic gases as the major object to be controlled in the volcanic disaster as a whole.
\end{abstract}

Key words : Miyake Island, volcanic disaster, mudflow damage, volcanic gases, countermeasures for disaster restoration, development process

キーワード：三宅島，火山災害，泥流被害，火山ガス，復旧事業，展開過程

I. はじめに

三宅島は東京から南南西へ約 $180 \mathrm{~km}$ に位置す る直径約 $8 \mathrm{~km}$ ，面積約 $55 \mathrm{~km}^{2}$ ，周囲約 $35 \mathrm{~km}$
の円形の火山島である（図 1）。2000 年 6 月に始 まった三宅島の噴火活動は，度重なる噴火により 大量の火山灰を降らせ，その後の大雨により火山 灰は泥流となり，家屋や道路などを破壊した（相

* 東京都環境局

* Bureau of Environment, Tokyo Metropolitan Government 


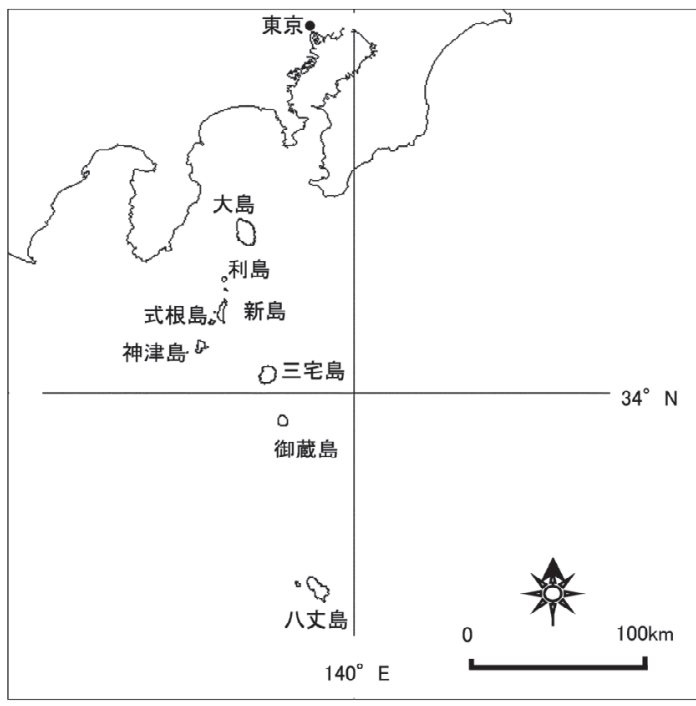

図 1 三宅島位置図.

Fig. 1 Location map of Miyake Island.
場, 2003)。また，図 2 に示すように，同年 8 月 下旬からは火山ガスが連続的に放出され，9月下 旬には一日の放出量が約 5 万トンという世界に 例をみないほど大量の二酸化硫黄が放出されるよ うになった（風早ほか, 2001)。このため，2000 年 9 月から 2005 年 1 月までの約 4 年 5 か月にわ たる間，三宅島の住民は島外避難を余儀なくされ た。2007 年 5 月現在においても，その規模は小 さくなったが，依然として火山ガスの放出が続い ている。

筆者はこれまでに，防災関係機関の環境変化の 認識と対応行動を明らかにすることを目的とし， 2000 年三宅島火山災害について，東京都災害対 策本部をはじめとした防災関係機関が行った災害 対策を時系列に空間的に把握することで，火山ガ スに関する安全確保対策の変遷について報告した （石原, 2006a）。全島民の避難が続く間，防災関 係機関は，火山ガスに対する安全対策の構築を進 めただけではない。泥流により被災した道路やラ イフラインの復旧，砂防ダムや治山ダムなどの泥

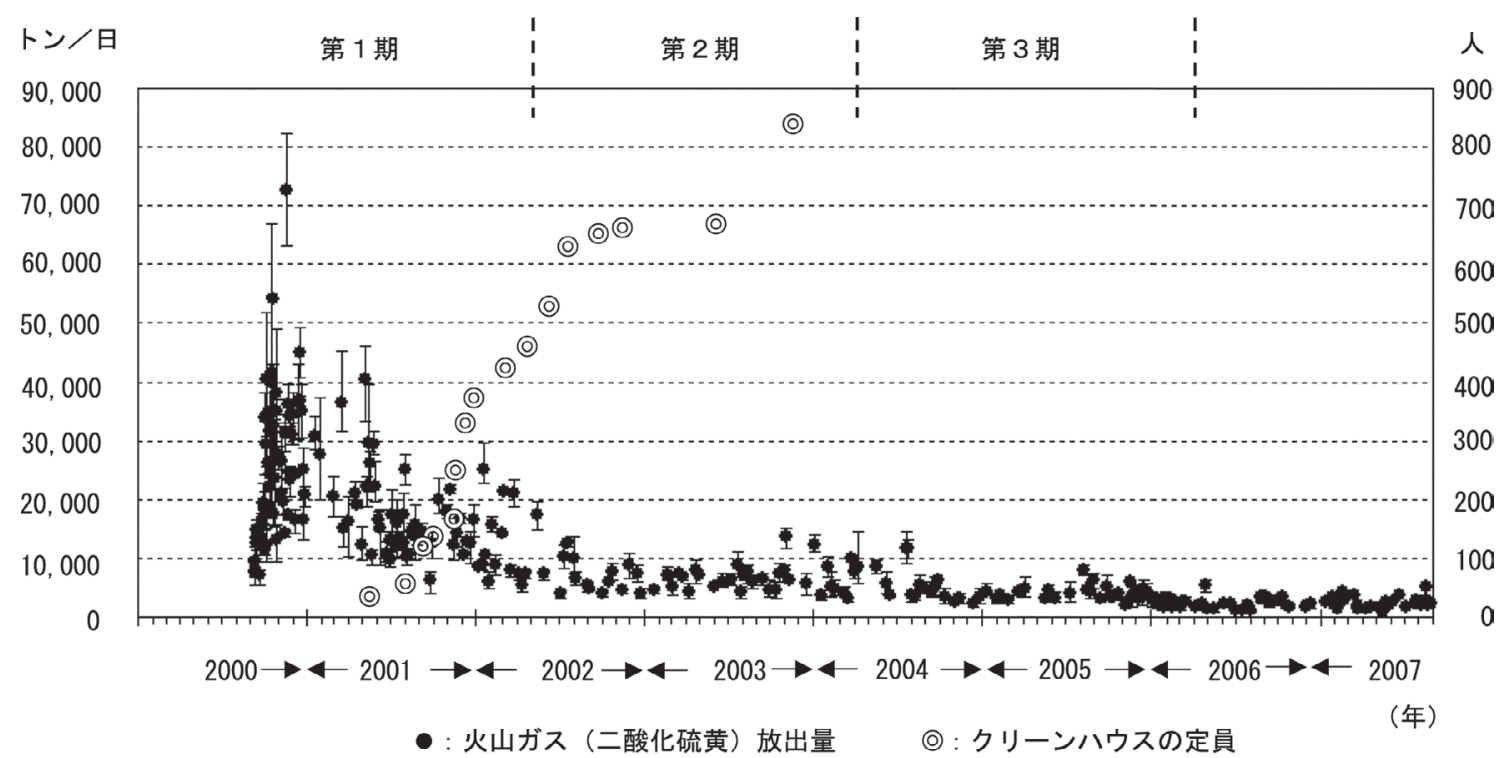

図 2 火山ガス (二酸化硫黄) 放出量およびクリーンハウス（脱硫装置の付いた施設）の定員の推移. 気象庁 $(2006,2007)$ および東京都総合防災部（2005）により作成.

Fig. 2 Changes in quantity of volcanic gases and capacity of clean houses. After Japan Meteorological Agency $(2006,2007)$ and Disaster Prevention Division, Tokyo Metropolitan Government (2005). 
流対策のための施設整備に努め，火山ガスの放出 が続く中， 2005 年 2 月に島民の帰島が実現した。 帰島にあたっての条件は, 火山ガスに対する安全 対策のみならず，住宅や公共施設などの泥流に対 する安全の確保も必要とされた。

一般に災害が継続すると考えられる場合，行政 機関が意思決定する際に, 刻一刻と変化する災害 の発生状況や復旧状況を空間的・時間的に的確に 認識することが，組織内での意思決定を行う上で 不可欠なことである。このことが適切な対策を講 じていくための重要な前提となると考えられる。 自然災害が発生した際には，地方自治体では災害 記録を作成している場合が多い。しかし，これら の災害記録は，当該地域における事実の記載にす ぎないため，そのままでは他の地域で自然災害が 生じた場合に有益な資料とはなり難い状況にあ る。これらの記録を活用するには, 現象の推移と 対策の変遷を時系列的に，また空間的に整理し， どのような現象がどのように認識されたかを明ら かにしておく必要がある。

本稿では, 石原 (2006a) で火山ガス対策の変 遷を明らかにしたのと同様の問題意識をもって, 今回の三宅島火山災害のもう一つの特徵である泥 流災害に関して，泥流による被害状況とそれに対 する復旧事業や対策事業の展開過程を整理し, 模 式化を行う。これを通して, 火山ガスの放出が継 続する地域での泥流災害と復旧事業や対策事業の 進展との関係を明らかにし，防災関係機関がどの ように環境の変化を認識し，それに基づいてどう いった対策を行ったかについて一般化を試みた い。そのためには, 復旧事業や対策事業の実施箇 所について約 5 年半の時間軸で空間的に捉える ことが必要であり, 事実の記載の積み重ねを行 $j^{11}$ 。この模式化は, 今後他の火山地域におい て，火山ガスの放出が継続する類似の火山ガス災 害と泥流災害が発生した際の防災対策の検討にも 資するであろう。

\section{II. 火山灰の降灰と泥流の発生に伴う被害状況}

\section{1）火山灰の降灰と泥流の発生}

2000 年 6 月に始まった三宅島の火山活動では,
同年 9 月 2 日〜 4 日までの三宅島島民の全島避 難に至るまでの間, 合計 7 回の噴火が発生して いる。このうち 8 月 18 日の噴火が最大規模のも のであり, 噴煙高度は約 $15,000 \mathrm{~m}$ に達し, 全島 に火山灰が降下し，多くの噴石が降っている。火 口付近では $2 \mathrm{~m}$ を超す火山灰の堆積が認められ ており, 全島に大量の火山灰が堆積している（中 田ほか, 2001)。東京大学地震研究所 (2001) に よる主要な噴火イベントにおける噴出量の調査結 果によれば，8月 18 日の噴火により約 980 万 $\mathrm{m}^{3}$ の火山灰が噴出し, 7 回の噴火で噴出した火山灰 等の噴出物を合計すると約 2,200 万 $\mathrm{m}^{3}$ に達する ものと推計されている。三宅島の雄山山頂から麓 にかけ火山灰が大量に堆積したことにより，火口 付近から全方位に向け泥流が発生している。これ は，火山灰により山腹斜面が覆われることによっ て浸透能が低下して表面流が発生しやすくなった ため（水山, 1997）と考えられる。

山越ほか（2003）は, 雄山の環状林道より上 部の斜面には多くのガリーが形成され，雄山の環 状林道より上部の斜面に対するガリーの面積率が 約 $10 \%$ にまで達したと報告している。また，阿 部ほか（2002）は，裸地化した地域や降灰その ものが樹木に大量に付着して樹木が枯損した地域 では，面状侵食も認められたことを報告してい る。

東京都建設局・東京都三宅支庁（2006）が調 査した雨量と泥流の発生との関係をまとめたもの が表 1 である。最初に降灰による泥流が発生し たのは 2000 年 7 月 26 日からである。これは 7 月 8 日および 7 月 14 日〜 15 日に噴火が生じ, 大量の火山灰が島の北東部にもたらされたためで ある。その後, 8 月 18 日の最大噴火で全島に降 灰がおよび，いたるところで泥流が発生するよう になった。特に，2000年 9 月 5 日の日雨量 $116 \mathrm{~mm}$ の大雨によって泥流が発生した。その後 も連続降雨の場合や日雨量あるいは時間雨量が多 い場合に泥流が発生している。泥流の発生は, 2001 年になってからも続き, 1 月 26 日の日雨量 $117 \mathrm{~mm}$ の大雨によって広範囲にわたって泥流が 発生した。その後, 同年 5 月 23 日と 8 月 22 日, 


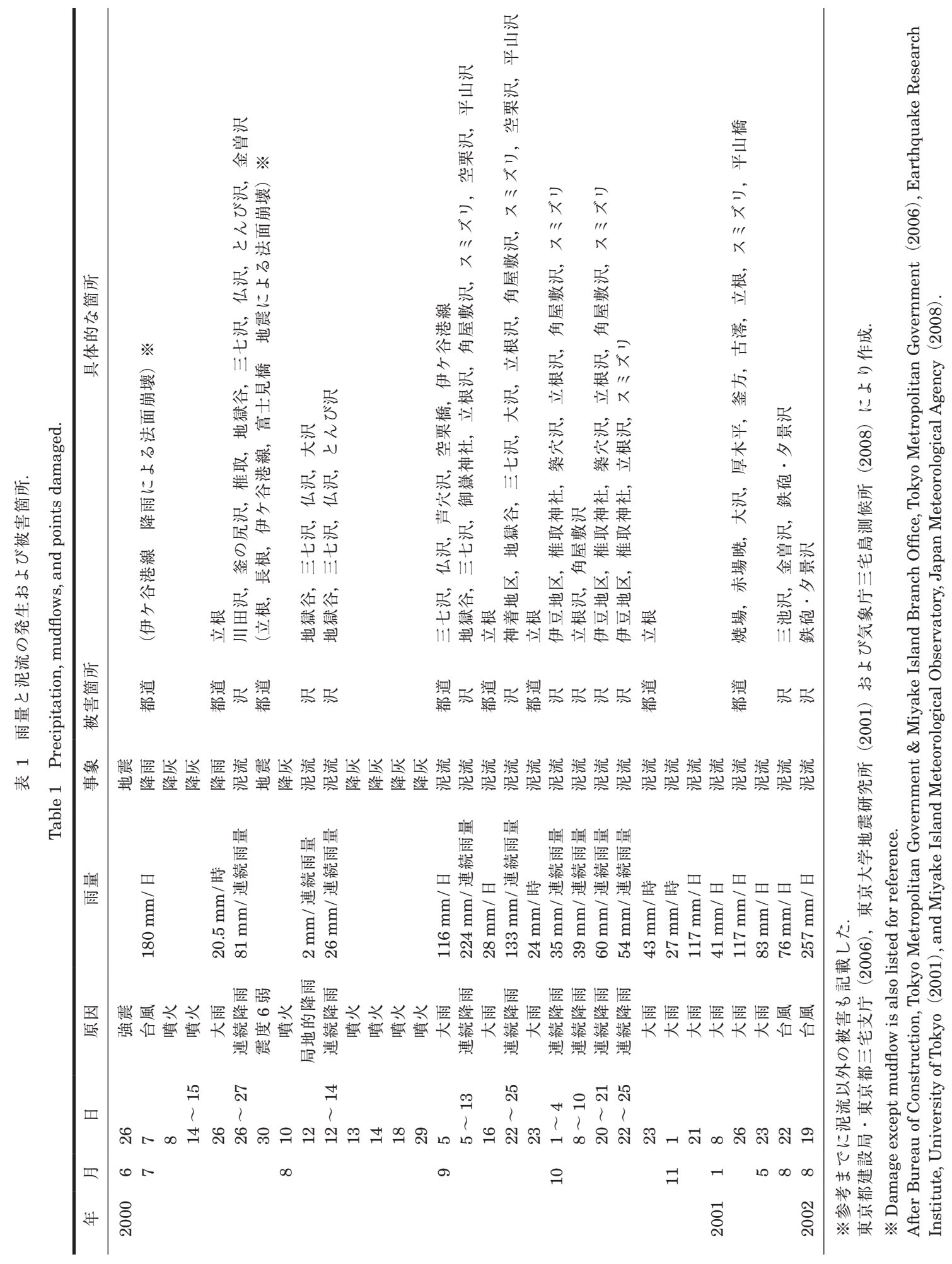


2002 年 8 月 19 日に泥流の発生が確認されてい るが，それ以降は 2001 年 1 月までにみられたよ うな大規模な泥流の発生は記録されていない。

\section{2）泥流による被害状況}

島民の避難後, 東京都現地災害対策本部および 防災関係機関は，2000 年 9 月 4 日からは東海汽 船より借り上げた大型客船「かとれあ丸」に移設 された。さらに，2000 年 10 月 7 日からは三宅 島の西北西約 $30 \mathrm{~km}$ にある神津島（図 1）の村 営ロッジ内に現地災害対策本部および防災関係機 関は移設された。現地災害対策本部および防災関 係機関によって, 三宅島火山活動の常時観測と主 要施設や通信施設等の荒廃を抑えるための島内作 業が実施されるとともに泥流等による被害状況の 把握が行われた。

現地災害対策本部により 2000 年 10 月 28 日 (植 生等については 7 月 30 日から 10 月 12 日の間) に目視により実施された調査（東京都災害対策本 部, 2000a）によれば，林道雄山環状線から上部 におけるヤシャブシなどの天然林は降灰によりす べて倒れ壊滅的状態になっていること，林道雄山 環状線周辺にあるスギなどの人工林の大半は降灰 により幹の先端や中程で折れ倒伏していること, これらより低地にある針葉樹では火山ガスにより 葉が赤色から茶褐色に変色していることが報告さ れている。また，林道雄山環状線では沢ごとに泥 流が発生し, 泥流は沢の河床を基盤岩に達するま で掘り下げているため, 林道の損傷が激しくなっ ていることも報告されている。

つぎに，現地災害対策本部により 2000 年 11 月 5 日に都道から目視で観察された調査結果（東 京都災害対策本部，2000b）によれば，三宅島東 部にある仏沢（図 3 の1), 三七沢（図 3 の(2)， 北東部にある地獄谷（図 3 の(3), 椎取神社付近 (図 3 の(4)), 釜の尻沢 (図 3 の(5)), 北部にある 坊田沢 (図 3 の6)，北西部にある伊ヶ谷沢（図 3 の (7)), 西部にある空栗沢（図 3 の8) で泥流 が発生し，島内を一周している都道あるいは村道 に被害を及ぼしていると報告されている。また, 釜の尻沢，坊田沢，伊ヶ谷沢においては，泥流が 家屋にまで流入していたとも報告されている。こ
のように泥流は火口付近から全方位に向け発生 し，道路や家屋に被害を及ぼしている。

さらに，現地竾害対策本部により 2000 年 10 月 16 日〜 18 日および 11 月 6 日に行われた調査 結果（東京都災害対策本部, 2000c）によれば, 泥流の流入により，三宅島北部にある湯の浜漁港 で泊地内の一部で水深が若干浅くなっているこ と，三宅島北西部にある伊ヶ谷漁港では船揚場施 設の約 3 分の 1 と物揚場の一部が使用不可能と なっていることが報告されている（図 4)。なお, その他の場所にある施設は, 一部で地盤沈下によ る被害があったものの，泥流による被害は特にみ られていない。また，三宅島南東部にある三宅島 空港（図 4）では，泥流の侵入とそれによる約 $50 \mathrm{~m}$ に及ぶフェンスの倒壊が発生していたが, 滑走路，エプロンなどの施設は使用可能な状態で あったと報告されている。

このほか, 2000 年三宅島火山災害においては, 降灰や泥流による被害とともに，2000 年の噴火 の際に伴う地震や， 5 年半にわたる全島避難中に おける火山ガスによる腐食などの被害も出てい る。しかし，本稿では，今回の三宅島火山災害の 特徵である泥流被害に対する復旧事業の進展を記 載することから，(1)泥流による被害を受けた道路 の復旧，(2)島外との交通確保のための港湾施設の 復旧，(3)災害復旧に従事する防災関係者が生活上 不可欠な水道施設の復旧，(4)泥流による被害を防 止するための砂防施設の整備，(5)腹の斜面を安 定化させるための治山施設の整備，以上について 着目する ${ }^{2)}$ 。

\section{III. 災害対策本部による復旧事業における 優先順位の意思決定}

\section{1）災害応急対策を行う上での制約}

前章でふれたとおり 2000 年 9 月 4 日以降，東 京都現地災害対策本部をはじめとする防災関係機 関は，大量に放出される火山ガスと泥流の度重な る発生の影響から，三宅島の島外に拠点を移した ため，島内で活動できる人員に大きな制約を受け ていた。また島内では，防災関係者が復旧作業等 に従事するにあたっての安全対策の観点から，降 


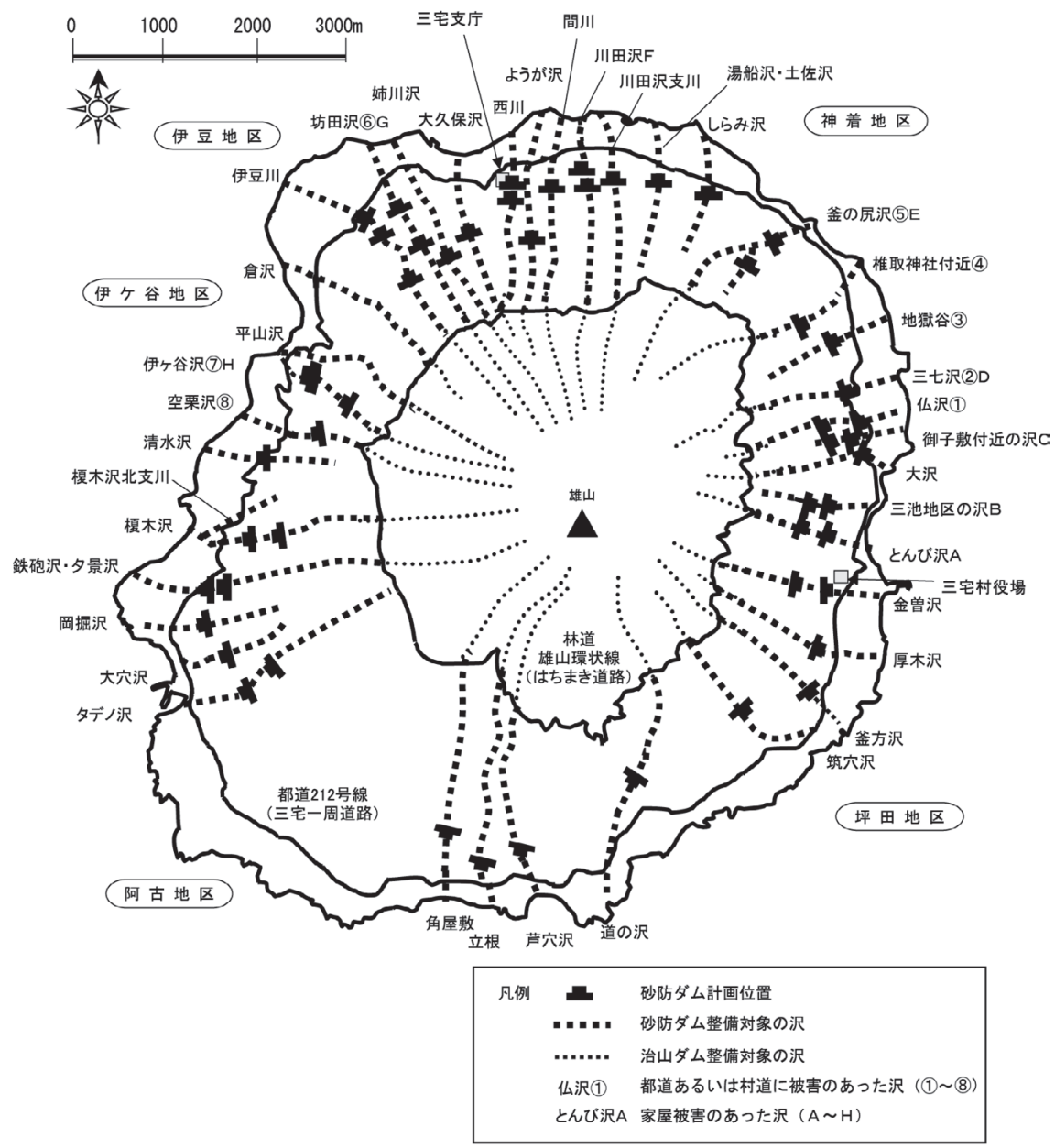

図 3 泥流発生に対する対策実施箇所.

東京都災害対策本部 $(2000 \mathrm{e})$ により作成.

Fig. 3 Measures enforcement points for flow outbreaks.

After Anti-disaster Headquarters of Tokyo Metropolitan Government (2000e).

雨に伴う泥流の発生による被害や火山ガスの放出 による被害を防止するため行動が制約されてい た。

気象庁の大雨注意報・警報の基準の変遷を表 2 に示した。2000 年火山災害が発生するまでの大 雨注意報・警報の基準は, 1 時間雨量で $30 \mathrm{~mm}$ ・ $50 \mathrm{~mm}, 24$ 時間雨量で $150 \mathrm{~mm} \cdot 300 \mathrm{~mm}$ とし ていた。同年 7 月に 2 回の降灰があり, その後 7 月 26 日〜 27 日に $81 \mathrm{~mm}$ に及ぶ連続降雨があっ たことから三宅島の東半分で泥流が発生した。こ
のことから， 7 月 27 日から暫定運用として大雨 注意報・警報の基準は, 1 時間雨量で $20 \mathrm{~mm}$ ・ $30 \mathrm{~mm}, 24$ 時間雨量で $50 \mathrm{~mm} \cdot 80 \mathrm{~mm}$ とされ た。さらに同年 8 月に入ってからも降雨に伴い泥 流が発生したため，同年 9 月 1 日に，気象庁は 8 月までの泥流の発生状況を参考にして，大雨注意 報・警報の基準を 1 時間雨量で $5 \mathrm{~mm} \cdot 10 \mathrm{~mm}$, 24 時間雨量で $10 \mathrm{~mm} \cdot 30 \mathrm{~mm}$ に変更するとと もに，新たに島内作業基準が設けられた。 また，2000年 12 月 8 日に，政府非常災害対 

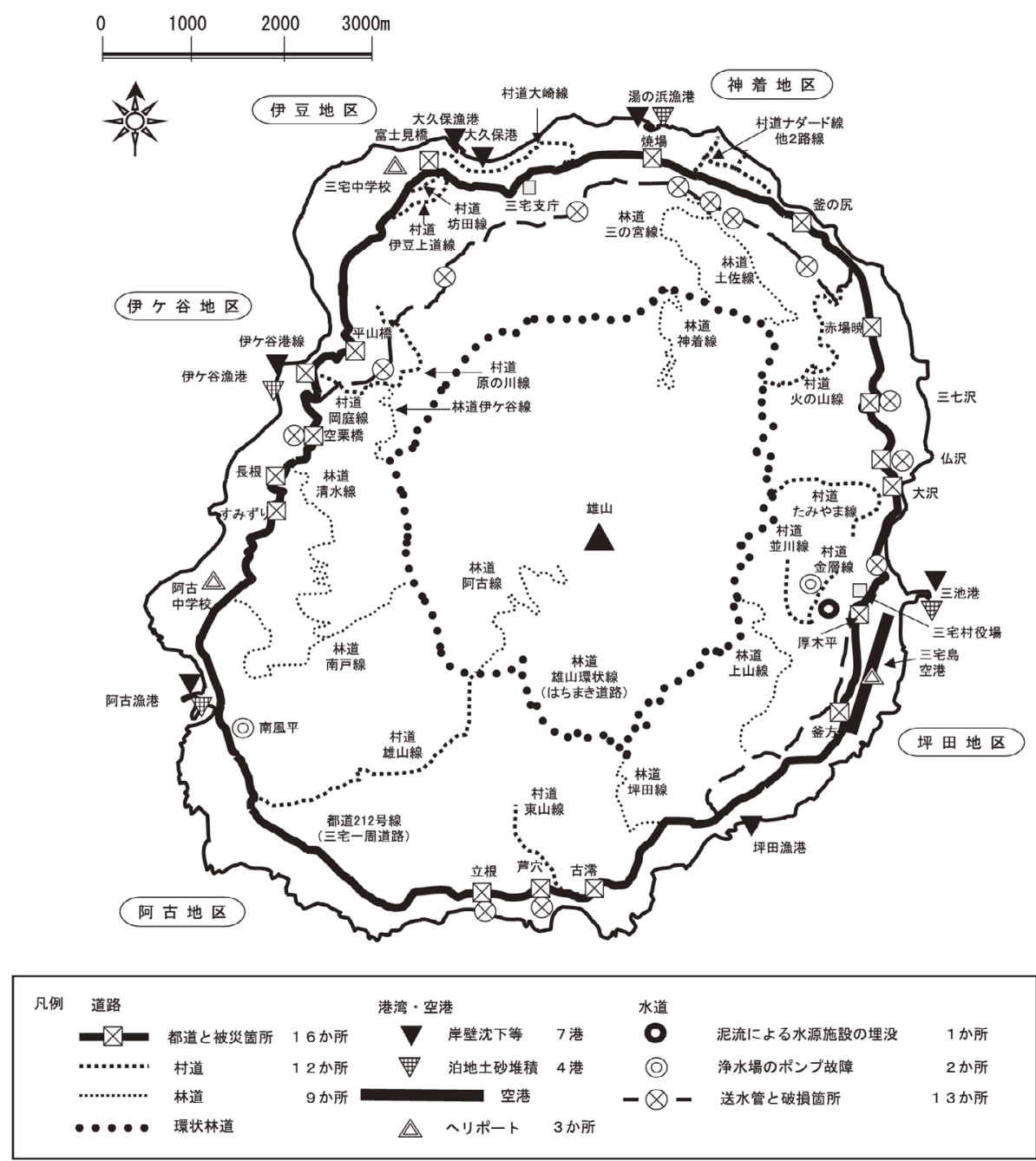

図 4 道路・港湾施設・水道施設の泥流による被害箇所. 東京都災害対策本部 $(2000 \mathrm{e}, 2001 \mathrm{a})$ により作成.

Fig. 4 Damage to points of infrastructure caused by mudflows. After Anti-disaster Headquarters of Tokyo Metropolitan Government (2000e, 2001a).

策本部および東京都災害対策本部は，「三宅島島 内作業等にかかる今後の進め方等について」を決 定している（東京都災害対策本部, 2000d）。この 決定で示された作業方針の主要な点として, (1)火 山活動の状況をふまえ, 初めて三宅島全域を危険 性からゾーニングし，それぞれの区域での安全確 保のための非常時の行動基準等を設定した，(2)島 内作業において, より安全性を高めるため, 従来 の火山対策の指針に防毒マスクを装着しての作業
に際しての遵守すべき事項を新たに盛り込むこと とした，(3)これまで天候等により，遅れていた山 腹の火山観測機器の設置について, 自衛隊のへリ による集中的な運搬作戦を展開し, 山腹への機器 設置作業を本格的に実施することとした，の 3 点 が挙げられる。

\section{2) 災害応急対策の状況}

$(2000$ 年 7 月から 2001 年 4 月まで $)$

このような状況の中で，東京都現地災害対策本 
表 2 大雨注意報・警報の基準值の変遷.

Table 2 Changes to standard value of heavy rain warning.

従前基準

\begin{tabular}{lrcc}
\hline & 1 時間雨量 & 3 時間雨量 & 24 時間雨量 \\
\hline 大雨注意報 & $30 \mathrm{~mm}$ & $60 \mathrm{~mm}$ & $150 \mathrm{~mm}$ \\
大雨警報 & $50 \mathrm{~mm}$ & $100 \mathrm{~mm}$ & $300 \mathrm{~mm}$ \\
& 総雨量 $150 \mathrm{~mm}$ & & \\
\hline & & & \\
2000 年 7 月 27 日 & (暫定運用) & 3 時間雨量 & 24 時間雨量 \\
\hline & 1 時間雨量 & $30 \mathrm{~mm}$ & $50 \mathrm{~mm}$ \\
大雨注意報 & $20 \mathrm{~mm}$ & $50 \mathrm{~mm}$ & $80 \mathrm{~mm}$ \\
大雨警報 & $30 \mathrm{~mm}$ &
\end{tabular}

2000 年 9 月 1 日（2000 年 8 月までに発生した泥流のデータを用いて）

\begin{tabular}{|c|c|c|c|c|}
\hline & 1 時間雨量 & 3 時間雨量 & 24 時間雨量 & 島内作業基準 \\
\hline 大雨注意報 & $5 \mathrm{~mm}$ & - & $10 \mathrm{~mm}$ & 沢筋作業中止 \\
\hline 大雨警報 & $10 \mathrm{~mm}$ & - & $30 \mathrm{~mm}$ & 泥流氾濫区域避難 \\
\hline \multicolumn{5}{|c|}{2001 年 5 月 4 日（夜間滞在施設の試行に伴い改訂） } \\
\hline & 1 時間雨量 & 3 時間雨量 & 24 時間雨量 & 島内作業基準 \\
\hline 大雨注意報 & $30 \mathrm{~mm}$ & $60 \mathrm{~mm}$ & $150 \mathrm{~mm}$ & 沢筋作業中止 \\
\hline \multirow[t]{2}{*}{ 大雨警報 } & $50 \mathrm{~mm}$ & $100 \mathrm{~mm}$ & $300 \mathrm{~mm}$ & 泥流氾濫区域避難 \\
\hline & 総雨量 $150 \mathrm{~mm}$ & & & \\
\hline
\end{tabular}

2003 年 4 月 4 日（住民の一時帰島の実施に伴い改訂）

\begin{tabular}{|c|c|c|c|c|c|}
\hline & 1 時間雨量 & 3 時間雨量 & 24 時間雨量 & 島内作業基準 & 住民 \\
\hline 大雨注意報 & $10 \mathrm{~mm}$ & $25 \mathrm{~mm}$ & $75 \mathrm{~mm}$ & 沢筋作業中止 & 避難喚起 \\
\hline 大雨警報 & $25 \mathrm{~mm}$ & $50 \mathrm{~mm}$ & $150 \mathrm{~mm}$ & 泥流氾濫区域避難 & 避難実施 \\
\hline 大雨臨時情報 & $50 \mathrm{~mm}$ & $100 \mathrm{~mm}$ & $300 \mathrm{~mm}$ & 全島作業中止 & \\
\hline
\end{tabular}

2005 年 2 月 1 日（避難指示の解除 (帰島) に伴い改訂)

\begin{tabular}{|c|c|c|c|c|c|}
\hline & 1 時間雨量 & 3 時間雨量 & 24 時間雨量 & 島内作業基準 & 住民 \\
\hline 大雨注意報 & $20 \mathrm{~mm}$ & $35 \mathrm{~mm}$ & $100 \mathrm{~mm}$ & 沢筋作業中止 & 避難喚起 \\
\hline 大雨警報 & $30 \mathrm{~mm}$ & $60 \mathrm{~mm}$ & $200 \mathrm{~mm}$ & 泥流氾濫区域避難 & 避難実施 \\
\hline 大雨臨時情報 & $50 \mathrm{~mm}$ & $100 \mathrm{~mm}$ & $300 \mathrm{~mm}$ & 全島作業中止 & \\
\hline
\end{tabular}

気象庁 (2006) および東京都建設局・東京都三宅支庁 (2006) により作成.

After Japan Meteorological Agency (2006) and Bureau of Construction, Tokyo Metropolitan Government \& Miyake Island Branch Office, Tokyo Metropolitan Government (2006).

部をはじめとする防災関係機関は，2000 年 11 月における被害状況の公表以降も被害状況の把握 に努め，災害応急対策の方針について検討を行っ
ている。東京都災害対策本部は，2000 年 12 月 14 日に，「三宅島・道路の復旧及び泥流対策等に ついて」を決定している（東京都災害対策本部， 
2000e)。この決定の概要を以下に示す。

まず，道路の復旧対策をみよう。この時点での 道路の被害箇所は都道 16 か所, 林道 9 か所, 村 道 10 か所 $^{3)}$ が確認されていた。被害状況は，道 路の破損, 土砂堆積, 路面の凹凸など, 多岐にわ たっている。道路の復旧計画の概要（図 4) は以 下の 3 点について，いずれも段階的に実施する ことが示されている。すなわち，(1)火山活動観測 体制を強化する目的で, 山腹の観測機器設置箇所 までの通行を確保するため，林道雄山環状線の一 部を含む林道・村道の応急復旧を 6 路線で実施 し， 2000 年 12 月までに完了する，(2)都道の復 旧については復旧作業が可能となりしだい，まず 緊急用・工事用道路として最低限 1 車線を確保 するための仮復旧工事行い，つぎに普通車両が通 行できて本格的工事用車両の通行にも利用できる 2 車線道路を確保するための応急復旧工事を行 い, さらに恒久的な道路を構築する本復旧工事を 行う, (3)林道・村道の復旧については復旧計画を 策定する。

つぎに，泥流対策についてみると，被害状況と しては, 泥流により被害が発生した沢は 27 沢で あることが確認され（図 3 ），このうち 8 沢（三 宅島の東部にあるとんび沢（図 3 のA）, 三池地 区の沢 (図 3 の B), 御子敷付近の沢 (図 3 の C), 三七沢（図 3 の D), 北東部にある釜の尻沢（図 3 の $\mathrm{E}$ ), 北部にある川田沢（図 3 の $\mathrm{F}$ ), 坊田沢 (図 3 の $\mathrm{G}$ ), 北西部にある伊ケ谷沢 (図 3 の $\mathrm{H}$ ) ) で家屋被害があったことが確認されている。

対策の概要としては, 復旧作業が可能になりし だい，緊急対策を実施することとされている。砂 防事業については，緊急対策として，下流に集落 があり，大きな被害が予想される沢である 16 沢 （伊豆川，坊田沢，西川，川田沢，釜の尻沢， 三七沢，仏沢，御子敷付近，大沢，三池地区の 沢，とんび沢，道の沢，タデノ沢，榎木沢，榎木 沢北支川，伊ケ谷沢）において，砂防ダムや流路 工の整備を行うとともに, 泥流センサーを整備す ることとされている。また，本格的対策として は，新たに被災した沢を含めた 27 沢（上記 16 沢に，姉川，ようが沢，間川，椎取神社付近，地
獄谷，金曾沢，築穴沢，芦穴沢，立根，角屋敷， 空栗沢を加えたもの）を対象に，5か年で砂防夕゙ ム約 50 基を設置するほかに, 流路工や泥流セン サーの整備を行うこととされている。そのため, 2001 年度から火山砂防激甚災害対策特別緊急事 業としてこれらの整備が実施できるよう国に申請 がなされている。

また，治山事業については，緊急対策として， 下流に集落があり，大きな被害が予想される沢で ある 12 沢（間川，川田沢，釜の尻沢，椎取神社 付近，地獄谷，三七沢，仏沢，御子敷付近，大 沢，三池地区の沢，とんび沢，金曽沢)について， 災害関連緊急治山事業として治山ダム 40 基の整 備を実施することとされている。また，本格的対 策としては，新たに被災した沢を含めた 14 沢(伊 豆川, 坊田沢, 西川, 築穴沢, 道の沢, 芦穴沢, 立根，角屋敷，タデノ沢，榎木沢，空栗沢，伊ケ 谷沢，平山沢，倉沢）で，治山ダム約 100 基の 整備をするほかに土留工や緑化工を行うこととさ れている。これらの整備については, 砂防事業と 同様に，2001 年度から火山治山激甚災害対策特 別緊急事業として実施できるよう国に申請されて いる。

これらのことから, 島民の全島避難から 3 か 月半程度の時点で，防災関係機関は泥流の発生や 道路の被害状況を把握し，復旧の優先順位をおお むね決定していることがうかがえる。すなわち， 島内一周道路の復旧と泥流による被害軽減のため の対策が最も重要であることを認識していたもの と考えられる。この決定の時点では，神津島に東 京都現地対策本部が移設されており，三宅島に渡 島して作業にあたることができる人員数は制約さ れた状況になっていたため，この決定で作業の優 先順位を明確にすることが必要であったと考えら れる。

\section{3）三宅島泥流対策・インフラ復旧プロジェク トチームの設置}

2000 年 12 月 14 日に決定された「三宅島・道 路の復旧及び泥流対策等について」では，この決 定以後の対策の検討体制として，関係機関で構成 する三宅島泥流対策・インフラ復旧プロジェクト 
チーム4) を設置することとされている。同チー ムでは, 三宅島の泥流対策およびインフラ復旧に 関して，各所管事業の内容，スケジュール等を調 整し，復旧から復興へ向けての道筋を明らかに し，また，節目ごとの状況を公表するなど，島民 の生活再建に資するため，検討を進めることとさ れている。2001年 2 月 23 日に, 同チームでの 検討結果をふまえて，東京都災害対策本部 （2001a）は，「三宅島のインフラ復旧及び泥流対 策等について」を決定している。この決定では, 火山活動観測体制の強化を図るとともに，2000 年 12 月 14 日に決定した「三宅島・道路の復旧 及び泥流対策等について」をふまえ，港湾施設や 水道施設のインフラストラクチャーの復旧につい て新たに方針が示されているので，以下にその要 点を示す。なお，この決定において村道の復旧箇 所が 2 か所追加された。

港湾関係では（図 4), 現況として三池港と阿 古漁港で資材運搬の貨物船等の一部暫定使用開始 に向けて航路・泊地の浚渫が実施されているこ と, 坪田漁港と湯の浜漁港で仮設係留施設を設置 することで一部暫定使用が開始されていること, ヘリポートについては三宅島空港に加え三宅中学 校と阿古地区の仮設へリポート計 3 か所を確保 済みであることが記されている。また，三宅島空 港については，滑走路の泥流除去等により，施設 を使用可能にすることが示されている。

さらに，水道関係については（図 4), 金層第 2 水源での泥土が除去され，金層第 1 水源ポンプ および南風平第 1 水源ポンプの取替がなされ，送 水管の復旧が 6 か所で実施されていることや, 三 宅村役場や三宅支庁等活動拠点へ水の供給が行わ れ，生活用水が確保されていることが記されてい る。また，生コンプラントなどの工事用資材供給 施設への給水の準備が進められていることが示さ れている。

なお，この決定では，本格的なインフラ復旧お よび泥流対策などについては，三宅島で夜間滞在 しての常駐作業が可能となりしだい，応急復旧お よび本格復旧を段階的に実施していくこととされ ている。そのため，専門家などを中心に，三宅島
の夜間滞在を実施するための観測，安全確認，復 旧のための技術的調査なども行うこととされてい る。

このように 2000 年 8 月の大規模な降灰とそれ に伴う全島で生じた泥流被害の発生に対して，東 京都災害対策本部は半年後の 2001 年 2 月に応急 復旧と本格復旧の方針を定めている。すなわち, 特に早急に実施する必要がある事業として，すべ ての復旧事業を実施する上での骨格的な施設であ る都道の復旧，復旧工事拉よび関係者滞在のため の水道・電気・通信などのライフラインの確保, 泥流の発生を抑止するための泥流防御施設の整 備，火山観測機器の保守点検のために必要な林道 の復旧，物資搬入用港湾の復旧などが位置づけら れた。これら以外は，上記とともに早急に実施す る必要のある事業あるいは帰島の見通しがたった 後に実施する事業として位置づけられた。東京都 災害対策本部が発災から約半年の期間でこの方針 を定めたことは，火山ガスの発生により，島内で の応急復旧や被害調査などの活動に制約を受けな がらも，迅速にかつ的確に対応したことを示すも のと考えられる。

\section{4）三宅島災害対策技術会議の設置}

2001 年 4 月 17 日に，東京都災害対策本部 （2001b）は，翌 18 日に都道の通行を島内全周に わたって確保することを発表している。この発表 は，三宅島を一周する都道 212 号線のうち, 2000 年 9 月下旬以降通行不能となっていた島南 部の立根地区（図 4）での仮橋設置工事が 2001 年 4 月 18 日に完了したことによるものである。 このことにより立根地区での通行が可能になった ことで，島内全周にわたり緊急時などでの通行が 可能となり，災害応急対策を終えたと捉えること ができよう。

また，同日 4 月 17 日に，東京都災害対策本部 （2001c）は，三宅島災害対策技術会議の設置を 決定している。三宅島における災害復旧活動につ いては，前節に示したとおり，それまでは東京都 災害対策本部の下に設置した三宅島泥流対策・イ ンフラ復旧プロジェクトチームにおいて，各事業 間の協議・調整が行われてきた。しかし，本格的 
な復旧に向けた新たな展開が必要とされたことか ら，三宅島災害対策技術会議を編成し，ここで技 術上の検討や連絡調整を行うこととされたもので ある。同会議の目的は，それまでの応急的な対策 等に加え，本格的な復旧に向けた総合的な検討や 復旧作業の効率に大きく影響する夜間常駐化の動 きなど現地の作業環境との調整を十分図りながら 進行管理等を行っていくこととし ${ }^{5)}$, 第 1 回会議 (2001年 5 月 7 日) 以降， 2006 年 3 月まで毎年 2 回〜 4 回の頻度で会議が開催されている。

東京都災害対策本部の下に設置されていた三宅 島泥流対策・インフラ復旧プロジェクトチーム は，建設局河川部が中心的主幹となり道路や港湾 等のインフラ施設を所管する機関で構成して検討 が進められてきた。一方，三宅島災害対策技術会 議も東京都災害対策本部の下に設置されたが，同 会議は総務局総合防災部が中心的主幹となり, 財 務局・環境局・衛生局（現在, 福祉保健局) - 教 育庁といったインフラ施設を所管する以外の部局 が参画した点で三宅島泥流対策・インフラ復旧プ ロジェクトチームとは異なっている。このこと は，災害応急対策を終え，以降の本格的な復旧事 業を進める上で，よりいっそうの東京都庁での全 体的な調整が必要であり，そのためには総務局総 合防災部が組織横断的な調整を図る上で中心的主 幹となった方が的確に事業を進めやすいと判断さ れたためと考えられる。

\section{IV．復旧事業の展開過程}

ここで，2000 年 9 月の島民の全島避難から， 2005 年 2 月の島民の帰島を経て 2006 年 3 月ま での 5 年半にわたる期間を， 3 つの期間に分けて 復旧事業や泥流対策事業がどのように展開した か，その過程をみよう。

\section{1）第 1 期 都道およびその近辺を中心とした} 復旧 $(2001$ 年 4 月から 2002 年 3 月まで $)$

2002 年 3 月までの復旧事業の進渉状況を図 5 に示した。都道については，16 か所の被災箇所 のうち 6 か所で復旧工事が完了している。また, 村道についても 7 か所で復旧工事が完了してい る。都道や村道の復旧によって通行が可能になっ
た箇所での水道施設の復旧も進められている。

砂防施設については, 都道から通行が可能な位 置の 15 か所で整備が進められている。また, 2001 年に火山砂防基本計画が策定され，この計 画の中で 2001 年から 5 か年で整備する緊急対策 の対象溪流として図 3 に示す 41 沢が位置づけら れるとともに，恒久対策の必要な沢として 227 沢が上げられている（東京都建設局・東京都三宅 支庁, 2006)。

一方，治山事業については，緑化による土砂流 出抑制を目的に，山腹に設置されていた村営牧場 付近において，牧草の種子の空中散布による緑化 工が 2001 年 6 月に試行された。しかし，牧草は 発芽したものの，火山ガスの影響によりわずかの 期間で枯死してしまうという結果であったため, それ以降は牧草の種子の空中散布による緑化工は 行われていない。

ここで復旧事業が進渉した背景をみよう。 2000 年 9 月から 2001 年 5 月までの間，東京都 災害対策本部は火山ガスを回避するため現地災害 対策本部を洋上や神津島に設けてきた。しかし， 作業効率の向上を図る上で三宅島において滞在す ることが不可避となり，東京都災害対策本部は夜 間に火山ガスによる被災を避けるため脱硫装置の 付いた施設（以下，クリーンハウスという）の整 備を試みている。2001 年 5 月に，三宅支庁庁舎 にクリーンハウスが整備され，三宅島島内におけ る夜間滞在の試行が開始され，火山ガス放出下に おいても夜間滞在することが可能であることが実 証された。

この結果を受けて，2001年 6 月 29 日に，政 府非常災害対策本部および東京都災害対策本部 は，同年 7 月 9 日を目途に一般の工事関係者も 含めた本格的な夜間滞在を開始する旨の「三宅島 島内における作業等の今後の進め方について」を 公表している（東京都災害対策本部, 2001d）。こ れには，当面は 150 人規模で夜間滞在を実施し， 最終的には同年 8 月中を目途に 300 人規模の夜 間滞在を行い，泥流対策等を効率的かつ集中的に 行うとの予定が示され，クリーンハウスの整備が 進められた。クリーンハウスの整備に伴う定員の 


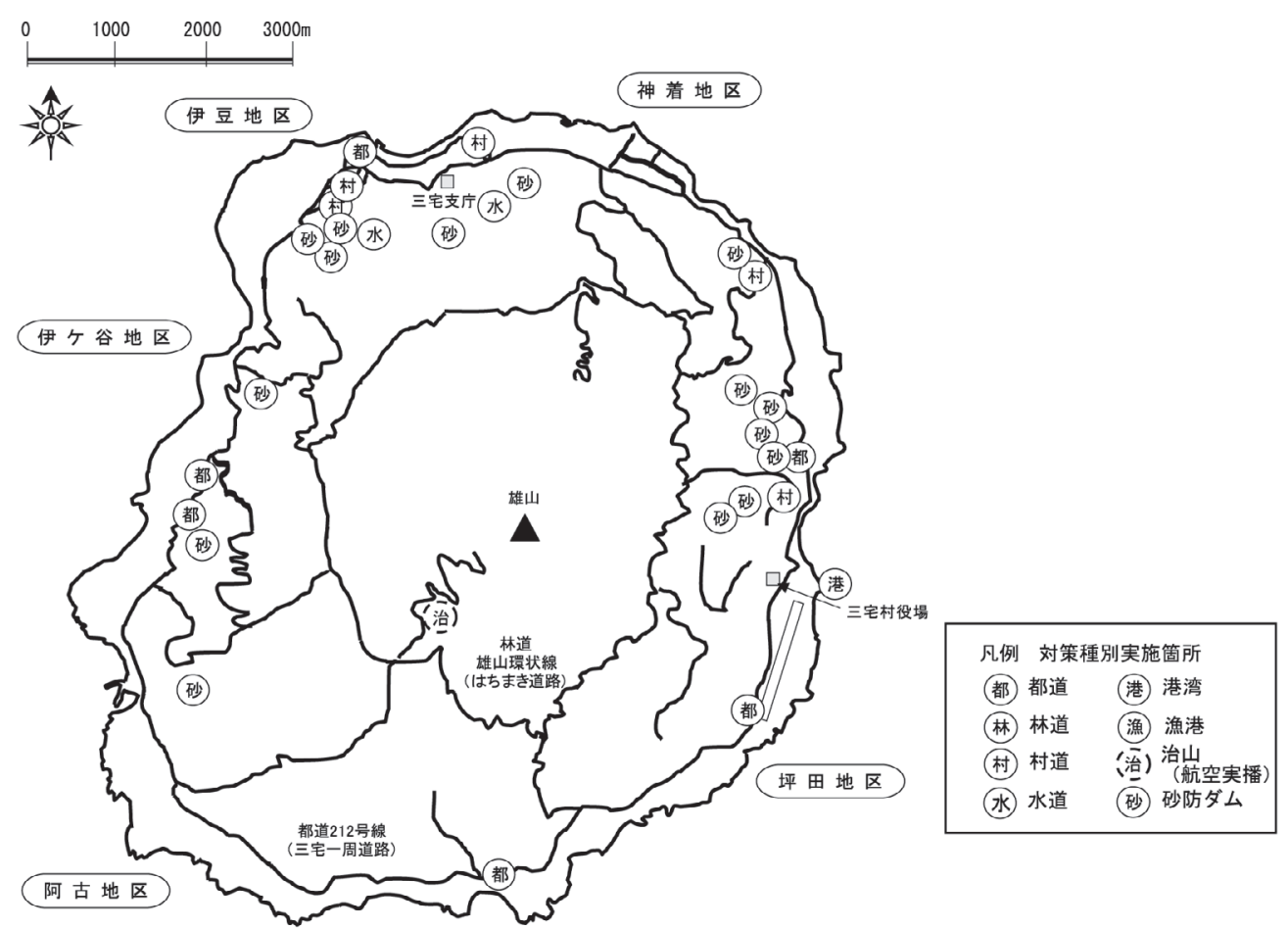

図 52001 年 4 月から 2002 年 3 月までの対策完了箇所（第 1 期). 東京都災害対策本部（2002）により作成.

Fig. 5 Points for which measures were completed from April 2001 to March 2002. After Anti-disaster Headquarters of Tokyo Metropolitan Government (2002).

推移については図 2 に示したとおりである。 2002 年 1 月までの間に，まず三宅村，三宅島警 察署，東京電力大久保発電所などの防災関係機関 で脱硫装置が整備され，その後は東京都の勤労福 祉会館および船客待合所や三宅村のふるさと館な どの公共施設に脱硫装置を整備する方法で，道 路, 砂防, 港湾などの復旧事業に従事する作業員 向けクリーン八ウスが整備され，以降復旧事業が 進捗した。

つぎに，この期間における復旧事業への泥流に 関連する制約をみると, 三宅支庁庁舎へのクリー ンハウスの整備による夜間滞在の試行に伴い, 2001 年 5 月 4 日に気象庁は表 2 に示すように大 雨注意報・警報の基準を改訂し, 従前基準に戻っ ている。また，復旧事業に従事する作業員の泥流 に対する安全確保を図るため，2001年 8 月に東 京都災害対策本部は「三宅島作業員用泥流防災
マップ」（東京都災害対策本部, 2001e）を作成し， 三宅島工事施工のための作業方針と留意事項を付 して工事請負会社等に配布し，復旧事業における 安全確保に努めている。

\section{2) 第 2 期 都道の完全復旧と泥流対策の推進} $(2002$ 年 4 月から 2004 年 3 月まで $)$

2002 年 4 月から 2004 年 3 月までの復旧事業 の進渉状況を図 6 に示した。工事関係者向けの クリーンハウスが 2001 年 11 月までに整備され たことから，工事に従事できる人員が大幅に増大 し, 道路復旧や砂防施設の整備工事は順調に進め られて，都道の復旧は 2004 年 3 月までにすべて 完了した。また，工事現場へのアクセスが向上し たことから，砂防施設の整備も多くなされるよう になった。2002 年 7 月には，治山や林道関係の 工事関係者用クリーンハウスの整備が進んだこと と，環状林道へのアクセスのための林道が一部復 


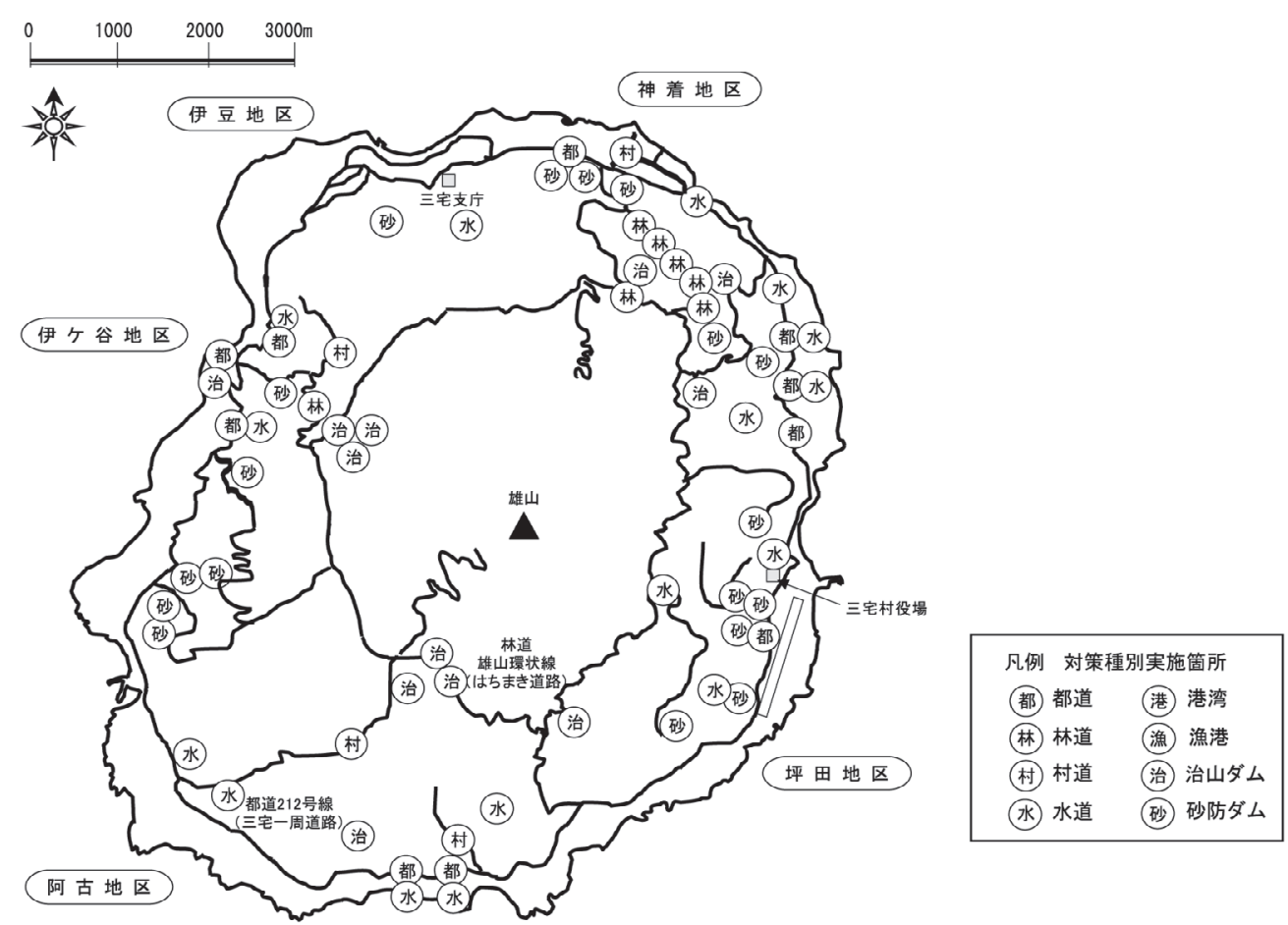

図 62002 年 4 月から 2004 年 3 月までの対策完了箇所（第 2 期）. 東京都災害対策本部 $(2002 ， 2004 ）$ により作成.

Fig. 6 Points for which measures were completed from April 2002 to March 2004. After Anti-disaster Headquarters of Tokyo Metropolitan Government (2002, 2004).

旧したことにより，治山施設の整備もはじめられ た。さらに，2003 年 3 月に公表された「三宅島 火山ガスに関する検討会報告書」（三宅島火山ガ スに関する検討会, 2003）により火山ガスの特性 が把握されたことによって，2003 年 12 月から 2004 年 1 月にかけて旅館・民宿を活用した工事 関係者用クリーンハウスが開設され，夜間滞在可 能人員数が増加している。この期間は都道周辺だ けでなく都道よりも標高の高い位置での復旧事業 が進んだ時期であるといえよう。

ライフラインを確保するための道路の復旧事 業, 泥流対策としての砂防事業などが急速に進め られたことで, 2003 年夏の時点では, 2004 年 3 月までに基幹インフラである島内一周道路の修復 を完了させ，泥流対策のための砂防ダムを計画基 数の約 $60 \%$ が整備される予定となっていた。砂 防ダムなどの整備が進められ，渓間工による対策
も効果を上げてきたと考えられていた一方で，火 山ガスの影響で牧草の種子の空中散布による緑化 工が不可能であること，災害地へのアクセスが困 難なこと, クリーンハウスの整備が 2002 年 7 月 までかかったことなどから，森林の回復は遅れて いるものと認識されていた。このため，2003 年 8 月に三宅島災害対策技術会議のもとに緑化関係 調整部会が設置され，森林を回復させるための 「三宅島緑化ガイドライン」策定の検討が開始さ れた6)。

なお，この期間における復旧事業への泥流に関 連する制約をみると， 2003 年 4 月からの住民の 一時帰島の実施に伴い，2003 年 4 月 4 日に気象 庁は表 2 に示すように大雨注意報・警報の基準 を改訂し, 厳しいものとしている。これは, 復旧 事業に従事する作業員だけの安全確保を考慮した ものから，一般住民が一時帰島した際の安全確保 


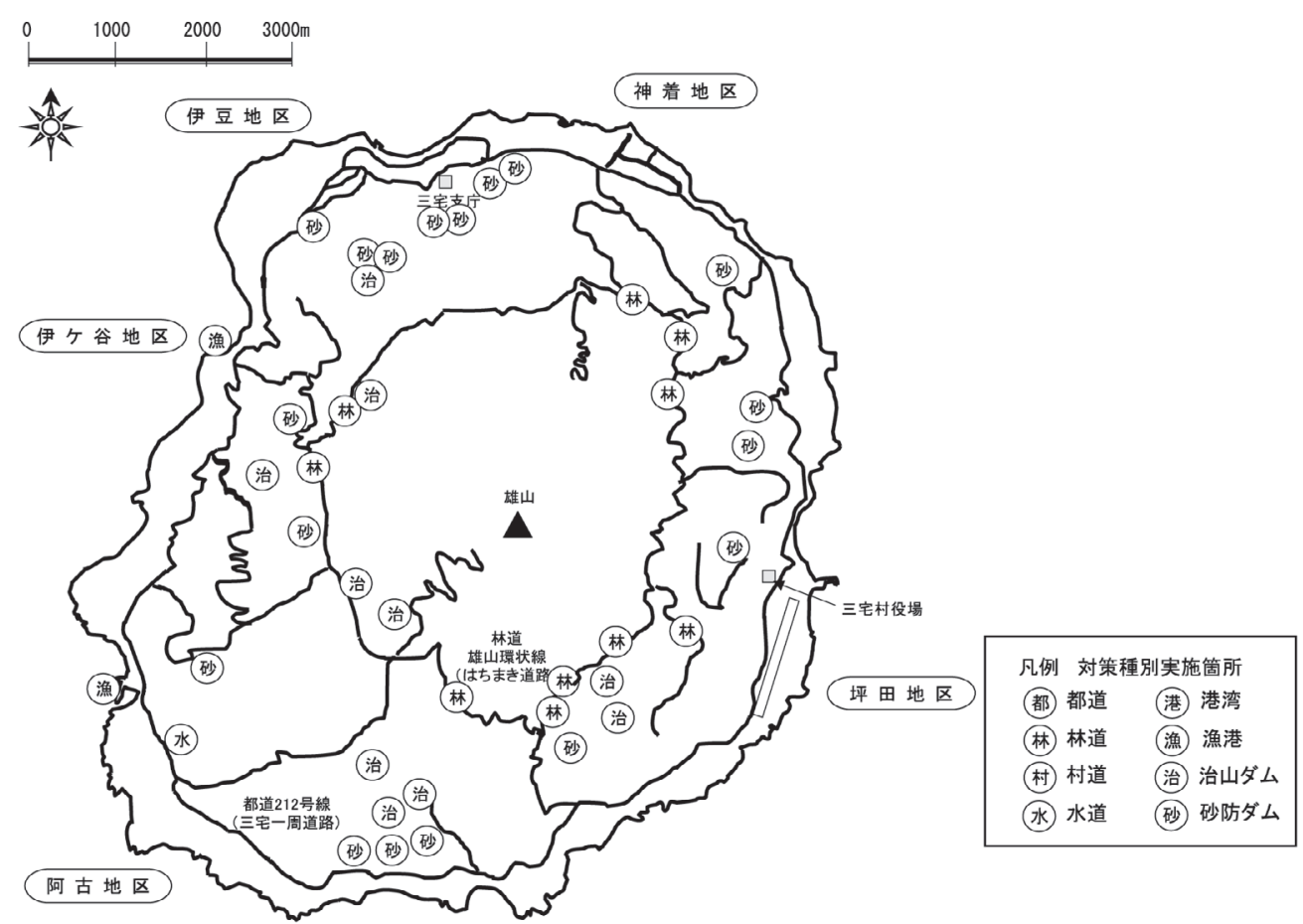

図 72004 年 4 月から 2006 年 3 月までの対策完了箇所 (第 3 期).

東京都災害対策本部（2004）および東京都総合防災部（2007）により作成.

Fig. 7 Points for which measures were completed from April 2004 to March 2006.

After Anti-disaster Headquarters of Tokyo Metropolitan Government (2004) and Disaster Prevention Division, Tokyo Metropolitan Government (2007).

を考慮したものとするためにとられた措置であ る。また，これにあわせて，東京都災害対策本部 は住民向けの「三宅島泥流防災マップ」（東京都 災害対策本部, 2003）を作成し，一時帰島した住 民に配布することで，当該住民への危険区域の周 知や泥流現象に関する普及啓発を図っている。

\section{3）第 3 期 山腹での復旧事業の展開}

\section{$(2004$ 年 4 月から 2006 年 3 月まで}

さらに 2004 年 4 月から 2006 年 3 月までの期 間の復旧事業の進渉状況を図 7 に示した。すで に都道の復旧は完了しており, 都道よりも標高の 高い位置での砂防施設の整備や林道の復旧も進 み，山腹地域へのアクセスが可能になった箇所で の治山ダムの整備などが中心になってきている。

また，2004 年 7 月に三宅村が，2005 年 2 月 に島民が州島する旨の帰島方針を発表した。この
ことを受け，東京都は直ちに三宅島帰島支援対策 本部を設置し（東京都総務局, 2004），2004 年 9 月に三宅島帰島支援緊急事業が実施されることに なった。この事業の中には，火山灰や火山ガスに より立ち枯れた枯損木の撤去を行う対策も含まれ ていた。帰島した島民が安心して島内での行動が できるようにするため，治山事業だけでなく砂防 事業や道路事業などが一体となって事業が進めら れている。

さらに, 2005 年 2 月の島民の帰島にあわせ, 三宅村は火山ガスに対する安全確保に関する条例 を施行している。この条例では，三宅島の一部の 区域において居住を制限する規定を設けたが，そ れ以外の区域ではクリーンハウス以外での夜間滞 在を可能としたものである。このことで，島民の 全島避難中には，島内に夜間滞在できる復旧事業 
に従事する人員数はクリーンハウスの定員内で あったが，帰島の実現以降は，この制約がなく なっている。また，この期間における復旧事業へ の泥流に関連する制約をみると，火山ガスへの対 策と同様に, 2005 年 2 月の帰島の実現に伴い, 2005 年 2 月 1 日に気象庁は表 2 に示すように大 雨注意報・警報の基準を改訂している。発災以降 の 2000 年 7 月から 8 月までの期間の暫定運用と 同等の水準まで戻っている。また，東京都災害対 策本部は 2003 年に住民向けに作成した「三宅島 泥流防災マップ」を改訂し，三宅村は 2005 年 5 月に改訂版である「三宅島泥流防災マップ」（三 宅村, 2005）を住民に配布した。

このように，東京都災害対策本部は，島民が州 島するまでの間，クリーンハウスの整備や旅館・ 民宿の活用を進めることによって，離島における 火山ガスの発生という制約を克服しながら, 2001 年 2 月に定めた本格復旧の方針に基づき, 復旧事業を的確に進め, 泥流に対する安全性を高 めてきたと考えられる。

なお，火山砂防激甚災害対策特別緊急事業押よ び火山治山激甚災害対策特別緊急事業は, 当初か ら予定されていた 5 か年にわたる対策事業を 2006 年 3 月に終えている。前者により, 計画基 数どおりに砂防ダムが整備された。また， 2004 年に火山砂防基本計画が見直され，2001年から 5 か年で整備する緊急対策の対象溪流である 41 沢（図 3）は計画どおり実施するものとされたが, 恒久対策の必要な沢は 227 沢から 100 沢に変更 され，当面は緊急対策の対象溪流である 41 沢を 対象とするとしている（東京都建設局・東京都三 宅支庁, 2006)。これは, 計画対象土砂量と計画 対象流木量の見直し結果をふまえた施設の基数 · 規模の見直し結果によるものであり，2006 年度 からは通常砂防事業だけが実施されている。一 方, 火山治山激甚災害対策特別緊急事業は, 2006 年度からさらに 2 か年を要することとなり, 引き続き治山ダムの整備が進められている。

\section{V. 復旧事業実施箇所の地形的位置の変遷}

これまで三宅島における 2006 年 3 月までの火
山泥流災害に関する災害応急対策および災害復旧 の経過を述べてきた。火山泥流災害にかかわる復 旧事業の展開過程は，IV 章で示したように3つ の時期に区分され，各時期における対策の実施箇 所はそれぞれ次のようにまとめられる。

第 1 期（2001 年 4 月〜 2002 年 3 月）では, 移動経路の確保，水道施設の復旧，ガス観測施設 の敷設などのため, 道路の復旧が最も重視されて いた（図 5)。また，泥流によるさらなる被害を 軽減するため, 砂防施設の整備が優先されてい た。このため, 復旧事業は海岸に沿って島を一周 する都道周辺での復旧を中心としていた。これら のことは, 山頂から島の全方位に泥流が発生し, 島内を一周している都道の 16 か所が寸断されて おり，この機能回復が何よりも優先されたからで ある。ことに，火山ガスの放出が続く中，クリー ンハウスが整備されるまでの間は，洋上や神津島 に現地災害対策本部を設置せざるを得ず，三宅島 での島内作業に従事する人員数が制約されたこと から，復旧事業の対象に関する優先順位が明確に なされた結果といえよう。

第 2 期（2002 年 4 月〜 2004 年 3 月）では, 都道の復旧が完了し, 砂防施設の整備が多くなさ れるようになった（図 6)。また，気象観測機器 を設置するために雄山中腹にある環状林道への通 行が確保され，この林道の復旧に伴って治山施設 の整備がはじめられた。この期間は，都道周辺だ けでなく都道よりも山側での復旧事業が進み始め た時期といえよう。これは，夜間滞在できる復旧 事業に携わる人員が大幅に増加したことや都道が 復旧したことで被災箇所への移動が格段に容易に なったこと等が要因であると考えられる。

第 3 期 (2004 年 4 月〜 2006 年 3 月) をみると, すでに都道の復旧は済んでおり, 復旧事業は都道 よりさらに標高の高い位置において, 砂防施設の 整備や治山施設の整備などが主に行われてきた (図 7)。この時期は，火山ガスの放出量が低下し てきたとともに，2005 年 2 月の島民の帰島にあ わせて，三宅村が条例を制定することによって火 山ガスに対する安全確保対策が確立されたこと で，夜間滞在における人員の制約がなくなり，復 


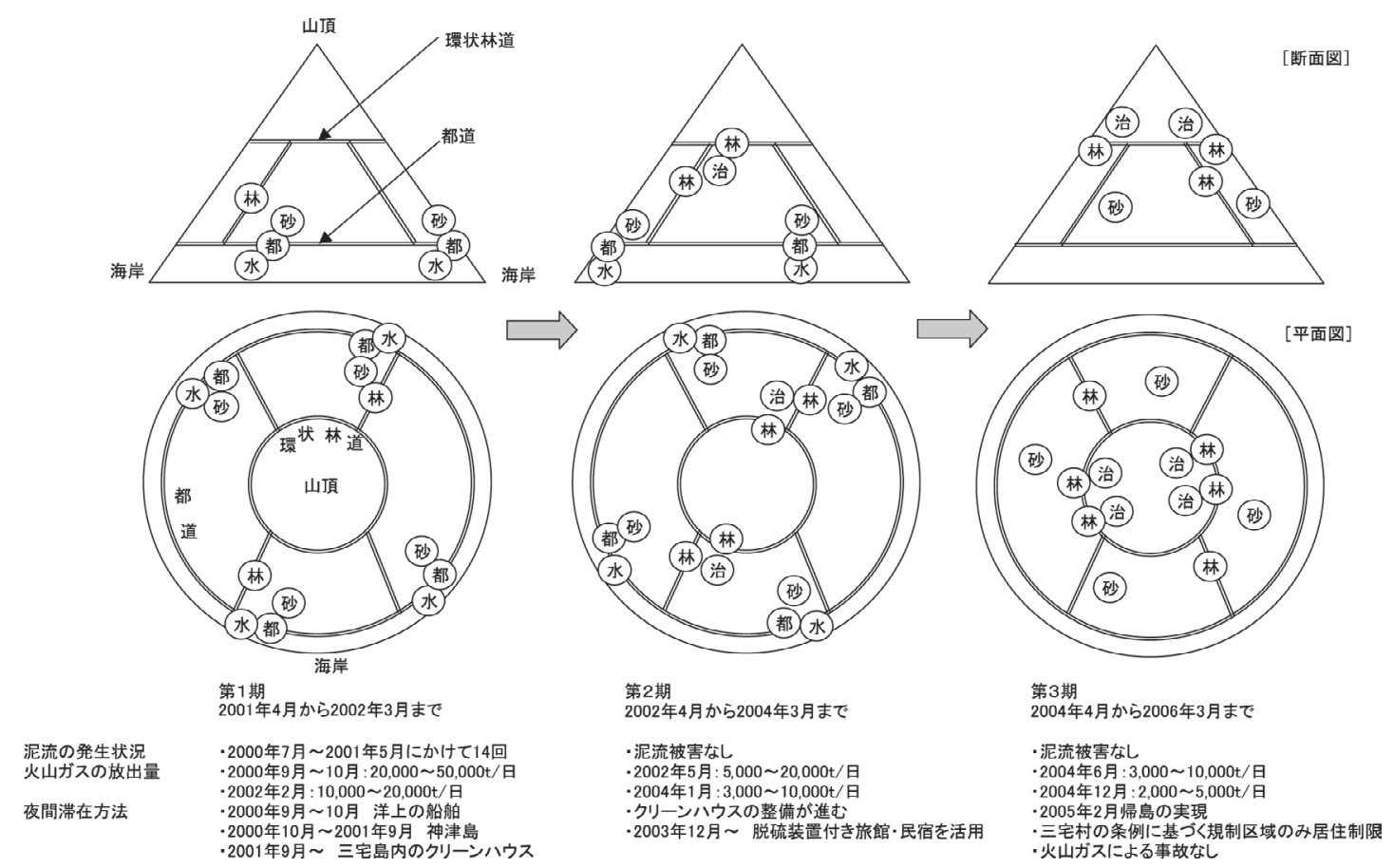

図 8 対策箇所の地形的位置に関する時間的変化の模式図.

Fig. 8 Diagram of topographic locations changed by measures enforced.

旧事業が進渉した。

前述のそれぞれの期間における復旧事業の実施 状況をもとに復旧事業の展開過程を模式的に示し たのが図 8 である。道路の復旧，砂防施設の整 備，治山施設の整備など，各事業の実施をみる と，時期ごとに優先される事業が異なっており， 復旧事業の実施箇所が空間的にも変化しているこ とが確認される。

一般的に火山泥流対策の全体計画を策定するた めの作業フローとして，まずは主な土砂生産源に 対する泥流発達防止ダムの整備が検討され，つぎ に住宅や公共施設などの保全対象域を考慮した流 路や砂防ダムの整備が検討される（水山, 1997）。 しかしながら，三宅島では火山ガスの放出が続い たため，被災箇所に立ち入る制約や復旧工事箇所 にかかわる人員上の制約があり，保全対象として 優先順位が高い都道の復旧事業や都道や集落を保 全するための砂防施設が整備された。このため標 高の低い位置にある都道やその周辺の集落から各
種対策が進められ，その後に標高の高い位置にあ る泥流発生箇所の対策を行わざるを得ないとうい う判断，すなわち泥流対策の展開戦略が行政機関 によって決定され，その順序に従い諸対策が講じ られてきたものと考えられる。この判断は，火山 ガスの放出が継続するという予測が十分できてい ない災害発生から約半年後という比較的早い時期 になされている。高濃度の火山ガスが放出され, 現地災害対策本部を洋上の船舶あるいは神津島に 置かざるを得なかった制約の大きい時期にもかか わらず，被災状況が早期に把握されたことで，長 期間にわたる泥流対策を的確に進めるための戦略 が構築されたものと考えられる。

また，施設の復旧や砂防ダムや治山ダムの整備 といった施設面での復旧事業が実施されてきた間 に，火山ガスの観測に基づく火山ガスの拡散する 方位の特性等の把握がなされるとともに，復旧事 業の進渉状況にあわせた大雨注意報・警報の基準 の見直し，泥流センサーの設置や泥流防災マップ 
の作成・改訂といったソフト面での泥流対策も進 められてきた。帰島に際して，三宅村が住民に対 して火山ガスに関する防災のしおりを配布しただ けでなく，地区別の詳細な情報を盛り达んだ「三 宅島泥流防災マップ」を提供したことは重要なこ とであると考える。

さらに，泥流の発生による公共施設や集落への 被害が減少し, 砂防ダムの整備が進展してから は，山麓に広がる枯損木が流木となることへの対 策に重点が移行し，面的な対策として緑化による 森林の回復の必要性が検討されてきた。砂防ダム の整備に係る全体計画が見直されるとともに，火 山ガスの放出が継続する中での森林復旧のあり方 が議論されたことは，砂防事業と治山事業とが連 携して行われた結果と言えよう。

本研究で得られた知見は, 今後, 離島において 各種復旧工事遂行の障害となる火山ガスの放出と いう条件下で火山災害による泥流被害が発生した 際に，復旧事業を行う上での参考になるものと考 える。これにとどまらず，本研究で用いた，行政 機関が実施した災害対策を時系列にまた空間的に 把握するという方法は, 行政機関が初めて直面し た自然災害現象をどのように認識し，その環境の 変化の認識に基づいてどのような対応行動をとっ たかという過程を明らかにする上で，有効な方法 となるものと思われる。

\section{謝 辞}

本稿で記した対策の実務は，東京都現地災害対策本 部をはじめとした防災関係機関の多数の職員・従事者 によってなされたものである。本稿は，東京都三宅島 災害対策技術会議に打いて作成した資料を参考として 記述をしており，本会議に参画した関係局の成果を活 用している。また，本稿の作成にあたり立正大学地球 環境科学部内山幸久教授, 田村俊和教授にご指導を 賜った。英文要旨の作成にあたり立正大学正井泰夫名 誉教授にご校閲を賜った。さらに，本稿は 2 名の査読 者による丁寧な查読により大幅に改善された。查読者 の一人である財団法人砂防フロンティア整備推進機構 井上公夫氏には，查読を通じて適切なご指摘をいただ いた。ご指導いただいた皆様に感謝申し上げる。
注

1）筆者は 2003 年 4 月に東京都三宅支庁に着任し, 2005 年 2 月の帰島に至るまで現地災害対策本部の一 員としてその運営にあたった。筆者の通常の職務は 産業課長であり，本稿に関する所管事業は治山事業， 林道復旧事業等であった。また，筆者が三宅支庁に 着任したのは 2003 年 4 月であるため，それ以前の東 京都災害対策本部の意思決定には参画していない。 したがって，本稿に関する復旧事業の展開過程の記 述は，東京都災害対策本部情報等の公表資料をもと に客観的に記載し考察したものである。

2）降灰や泥流による農地や宅地への被害もみられた。 農地の災害復旧については, 農家が州島して営農再 開することが前提であったため，2004 年 7 月の三宅 村による帰島方針発表後に手続きが開始された。詳 細ついては，石原（2006b）を参照のこと。また，住 宅の堆積土砂排除事業は，帰島方針が決定した 2004 年 7 月から 2005 年度中にかけて, 三宅村の事業とし て実施された。

3）東京都災害対策本部（2001a）が 2001 年 2 月 23 日に決定した「三宅島のインフラ復旧及び泥流対策 等について」では村道 2 か所が追加されており，図 4 はこの 2 か所を含め眓示した。

4) 三宅島泥流対策・インフラ復旧プロジェクトチー ムに関係する機関は，東京都の総務局・都市計画局 （現在，都市整備局）・労働経済局（現在，産業労働 局）・住宅局（現在，都市整備局）・建設局 - 港湾局 · 水道局，および，三宅村，東京電力（株），東日本電 信電話（株）である。

5）三宅島災害対策技術会議に関係する機関は，三宅 島泥流対策・インフラ復旧プロジェクトチームに関 係する機関に，東京都財務局・環境局・衛生局（現 在，福祉保健局）・教育庁の 4 機関を加えたものであ る。

6）「三宅島緑化ガイドライン」の策定に関する詳細に ついては，石原 $(2006 \mathrm{c})$ を参照のこと。

\section{文献}

阿部和時 - 黒川 潮 - 浅野志穂 - 岡本 隆 - 松山康治 · 落合博貴 - 寺嶋智已 - 島田和則 - 野口宏典 - 大丸 裕武・宮縁育夫・小川泰浩 (2002): 三宅島火山荒廃 地帯の土䁃浸食実態に関する実証的研究. 日本緑化 工学会誌, 28, 91-96.

相場淳司 (2003): 三宅島噴火災害と泥流対策. 土木学 会誌, 88(2), 50-53.

石原 肇 (2006a): 2000 年三宅島火山ガス災害一対策 の変遷一. 地学雑誌, 115, 172-192.

石原 肇 $(2006 b): 2005$ 年帰島後の三宅島における農 業復興対策. 地域安全学会梗概集， 19，51-54.

石原 肇 (2006c): 三宅島緑化ガイドラインの策定につ いて。植生情報， 10, 1-8.

風早康平 - 平林順一 森 博一 - 尾台正信 - 中堀康弘 野上健治・中田節也·篠原宏志・宇部浩三 (2001): 三宅島 2000 年噴火における火山ガス一火山灰の付着 ガス成分および $\mathrm{SO}_{2}$ 放出量から推測される脱ガス環 
境一. 地学雑誌, 110, 271-279.

気象庁 $(2006)$ : 平成 12 年 $(2000$ 年) 三宅島噴火及び 新島・神津島近海の地震活動調查報告. 気象庁技術 報告, 128 .

気象庁 (2007): 三宅島火山ガス (二酸化硫黄) 放出量. http://www.seisvol.kishou.go.jp/tokyo/320_Miyakejima/320_ So2emission.htm [Cited 2007/08/25].

気象庁三宅島測候所 (2008): 三宅島の過去の観測デー 夕.

http:/www.tokyo-jma.go.jp/home/miyakejima/ kakonodata.htm [Cited 2008/01/06].

三宅島火山ガスに関する検討会 (2003): 三宅島火山ガ スに関する検討会報告書. 内閣府・東京都.

三宅村 (2005): 三宅島泥流防災マップ. 三宅村.

水山高久 (1997): 火山の砂防. 宇井忠英編 : 火山噴火 と災害。東京大学出版会，166-181.

中田節也 - 長井雅史 · 安田 敦 - 嶋野岳人 - 下司信夫 · 大野希一・秋政貴子・金子隆之・藤井敏嗣 (2001)： 三宅島 2000 年噴火の経緯一山頂陥没と噴出物の特 徵一. 地学雑誌, 110, 168-180.

東京大学地震研究所 $(2001): 2000$ 年 7 月〜 8 月に堆 積した火山灰について (2001年 10 月 22 日版).

http://www.eri.u-tokyo.ac.jp/Jhome.html [Cited 2007/08/25].

東京都建設局・東京都三宅支庁 $(2006)$ : 平成 12 年三 宅島火山災害への取り組み一道路・海岸・砂防事 業一。東京都.

東京都災害対策本部 (2000a): 三宅島の現況調査結果 (農地, 山林等) について.

http://www.metro.tokyo.jp/SAIGAI/HISAI/MIYAK311. HTM [Cited 2007/05/03].

東京都災害対策本部 (2000b) : 三宅島の道路，河川の 調査結果について.

http://www.metro.tokyo.jp/SAIGAI/HISAI/MIYAK315. HTM [Cited 2007/05/03].

東京都災害対策本部 (2000c) : 三宅島の港湾, 漁港, 空港の調査結果について.

http://www.metro.tokyo.jp/SAIGAI/HISAI/MIYAK313. HTM [Cited 2007/05/03].

東京都災害対策本部 $(2000 \mathrm{~d})$ : 三宅島島内作業等にか かる今後の進め方等について。

http://www.metro.tokyo.jp/SAIGAI/HISAI/MIYAK331. HTM [Cited 2007/05/03].

東京都災害対策本部 $(2000 \mathrm{e})$ : 三宅島・道路の復旧及び 泥流対策等について.

http://www.metro.tokyo.jp/SAIGAI/HISAI/MIYAK339.

HTM [Cited 2007/05/03].
東京都災害対策本部 (2001a): 三宅島のインフラ復旧 及び泥流対策等について。

http://www.metro.tokyo.jp/SAIGAI/HISAI/MIYAK362. HTM [Cited 2007/05/03].

東京都災害対策本部 $(2001 b)$ : 三宅島一周都道・立根 （たつね）地区の仮橋が完成します一都道の通行を島 内全周にわたって確保一.

http://www.metro.tokyo.jp/SAIGAI/HISAI/MIYAK379. HTM [Cited 2007/05/03].

東京都災害対策本部 $(2001 \mathrm{c})$ : 三宅島災害対策技術会議 を設置します。

http://www.metro.tokyo.jp/SAIGAI/HISAI/MIYAK380. HTM [Cited 2007/05/03].

東京都災害対策本部 (2001d): 三宅島島内における作 業等の今後の進め方について。

http://www.metro.tokyo.jp/SAIGAI/HISAI/MIYAK398. HTM [Cited 2007/05/03].

東京都災害対策本部 (2001e): 三宅島作業員泥流防災 マップ。東京都.

東京都災害対策本部 (2002): 平成 14 年度第 1 回三宅 島災害対策技術会議の内容について。

http://www.metro.tokyo.jp/SAIGAI/HISAI/MIYAK456. HTM [Cited 2007/05/03] .

東京都災害対策本部 (2003): 三宅島泥流防災マップ. 東京都.

東京都災害対策本部 (2004): 平成 16 年度第 1 回三宅 島災害対策技術会議の内容について。 http://www.metro.tokyo.jp/SAIGAI/HISAI/MIYAK543. HTM [Cited 2007/05/03].

東京都総合防災部 (2005): 東京都の災害. 東京都.

東京都総合防災部 (2007): 三宅島災害対策技術会議資 料.

http://www.bousai.metro.tokyo.jp/japanese/knowledge/ pdf/miyakejima/Chapter01/09_Document.pdf [Cited 2007/05/03]

東京都総務局 (2004): 東京都三宅島帰島支援対策本部 の設置について.

http://www.soumu.metro.tokyo.jp/05gyousei/press/1603. pdf [Cited 2007/05/03].

山越隆雄 - 仲野公章 - 渡 正昭 - 水山高久 - 千葉達朗 (2003): 2000 年三宅島噴火後の雄山山腹斜面におけ るガリー形成特性. 砂防学会誌, $55(5), 40-48$.

(2007 年 6 月 25 日受付, 2008 年 2 月 18 日受理) 